\title{
Implementasi Pembelajaran Bervisi SETS di Sekolah
}

\author{
Sri Latifah \\ Fakultas Tarbiyah dan Keguruan, IAIN Raden Intan Lampung \\ srilatifah21@yahoo.com
}

\begin{abstract}
ABSTRAK
Pembelajaran tentang alam harus dapat disajikan sebagai suatu proses penemuan dan terkait dengan pengalaman peserta didik, sehingga pengetahuan yang diperoleh bersifat lama, dapat diingat, dan mampu meningkatkan penalaran siswa dan kemampuan untuk berfikir bebas. Peran pendidik sebagai narasumber yang bijak dan berpengetahuan serta berfungsi sebagai sutradara yang mengendalikan proses pembelajaran dan siap membantu siswa apabila ada kemacetan proses pembelajaran atau melantur tanpa arah. Wawasan SETS (Science, Environment, Technology, Society) yang diaplikasikan ke dalam proses pembelajaran Fisika diharapkan dapat membawa sistem pembelajaran untuk menghasilkan lulusan yang dapat menerapkan pengetahuan yang diperolehnya guna meningkatkan kualitas hidup manusia tanpa harus membahayakan lingkungannya.
\end{abstract}

\section{PENDAHULUAN}

Mempelajari alam dan sekitarnya adalah suatu hal yang relatif mudah. Karena keberadaan alam ini adalah sesuatu yang konkrit . Kita dapat mengindera apa saja yang ada di sekitar kita, diamati, dipelajari kemudian dapat digunakan untuk kemanfaatan umat seluruhnya. Kejadian alam dapat terjadi baik secara langsung maupun tidak langsung dengan diri manusia.

Kejadian yang ada berlangsung terkait dan berkesinambungan. Suatu sistem yang terjadi dapat menyebabkan terjadinya sistem yang lain. Dari setiap kejadian alam yang ada, dapat memunculkan pertanyaan - pertanyaan sebagai suatu permasalahan yang pada akhirnya dapat bermanfaat bagi manusia setelah mengalami verifikasi dan pengamatan. Oleh karena itu Pembelajaran Fisika memerlukan keterlibatan aktif para siswa.

Dari uraian di atas, maka pembelajaran tentang alam harus dapat disajikan sebagai suatu proses penemuan dan terkait dengan pengalaman peserta didik, sehingga pengetahuan yang diperoleh bersifat lama, dapat diingat, dan mampu meningkatkan penalaran siswa dan kemampuan untuk berfikir bebas. Menurut Bruner, belajar meliputi 3 proses kognitif yaitu : memperoleh informasi baru, transformasi pengetahuan, dan menguji relevansi dan ketepatan pengetahuan. Masih menurut Bruner belajar merupakan konseptualisme instrumental yang didasarkan pada 2 prinsip, yaitu : pengetahuan orang tentang alam didasarkan pada modelmodel mengenai kenyataan yang dibangunnya, dan model-model itu mula-mula diadopsi dari 
kebudayaan seseorang, dan kemudian model-model itu diadaptasikan pada kegunaan bagi orang itu.

Rendahnya hasil belajar mata pelajaran Fisika yang terukur pada nilai rata-rata ulangan umum maupun pada raport dibandingkan dengan mata pelajaran eksak lainnya seperti Biologi atau Kimia membawa keprihatinan para pendidik khususnya guru-guru Fisika. Selain itu minat yang rendah dari para siswa dalam mempelajari konsep-konsep Fisika dapat dilihat dari adanya anggapan umum siswa bahwa Fisika adalah mata pelajaran yang sarat dengan rumus, perhitungan, pemikiran, dan abstrak sehingga membosankan. Dengan kondisi pembelajaran Fisika seperti itu dan tidak adanya motivasi yang mendukung semangat belajar siswa menyebabkan ketuntasan pembelajaran relatif rendah. Selain itu hasil belajar Fisika tidak tercermin pada sikap dan perilaku siswa dalam kesehariannya. Siswa kurang memiliki cara pandang dan rasa peduli terhadap dampak positif maupun negatif dari ilmu Fisika yang memproduksi teknologi bagi masyarakat serta pengaruhnya terhadap lingkungan. Dalam proses pembelajaran ilmu Fisika keaktifan siswa merupakan inti dari pola belajar dengan pendekatan konstruktivis, hal itu dapat tercermin dari aktifnya para siswa membaca sendiri, mengaitkan konsep-konsep baru dengan berdiskusi dan menggunakan istilah, konsep dan prinsip yang baru mereka pelajari diantara mereka. Dalam pendekatan konstruktivis siswa secara aktif membangun pengetahuannya sendiri berdasarkan "apa yang diketahui siswa”. Sedangkan guru berperan sebagai narasumber yang bijak dan berpengetahuan serta berfungsi sebagai sutradara yang mengendalikan proses pembelajaran dan siap membantu siswa apabila ada kemacetan proses pembelajaran atau melantur tanpa arah. Laboratorium (lab) sebagai salah satu sarana sumber belajar merupakan salah satu alternatif proses pembelajaran Fisika dengan basis lab yang dapat menerjemahkan konsep-konsep abstrak ke dalam bentuk konkrit, mengapresiasikan permasalahan sehari-hari dalam masyarakat, teknologi dan lingkungan sekitar serta memecahkannya secara berpikir sistematis, analitis dan alternatif. Pada dasarnya mata pelajaran Fisika merupakan salah satu mata pelajaran sains yang diharapkan sebagai sarana mengembangkan kemampuan berpikir analitis deduktif dengan menggunakan berbagai konsep dan prinsip Fisika untuk menjelaskan berbagai peristiwa alam. Tujuan pembelajaran mata pelajaran Fisika SMA yang dicanangkan Depdiknas adalah agar siswa menguasai konsep dan prinsip Fisika untuk mengembangkan pengetahuan, keterampilan dan sikap percaya diri sehingga dapat diterapkan dalam kehidupan sehari-hari. 


\section{PEMBAHASAN}

\section{a. Konsep Pendekatan Belajar}

Menurut Rosser pendekatan Bruner terhadap belajar didasarkan pada dua asumsi, yaitu :

Pertama, bahwa perolehan pengetahuan merupakan suatu proses interaktif. Berlawanan dengan para pengamat teori perilaku, Bruner yakin bahwa orang yang belajar berinteraksi dengan lingkungannya secara aktif, perubahan tak hanya terjadi di lingkungan, tetapi juga dalam diri orang itu sendiri. Kedua, bahwa orang mengkonstruksi pengetahuannya dengan menghubungkan informasi yang masuk dengan informasi yang disimpan yang diperoleh sebelumnya (suatu model alam = model of the world). Konsep Belajar Bruner dikenal sebagai belajar penemuan (discovery learning), dengan penjelasan sebagai berikut :

1. Siswa berusaha sendiri untuk mencari pemecahan masalah serta pengetahuan yang menyertainya, menghasilkan pengetahuan yang benar-benar bermakna.

2. Siswa hendaknya belajar melalui partisipasi secara aktif dengan konsep-konsep dan prinsip-prinsip agar memperoleh pengalaman dan melakukan eksperimeneksperimen yang memungkinkan mereka memperoleh konsep baru.

Piaget menyimpulkan dari penelitiannya bahwa organisme bukanlah agen yang pasif dalam perkembangan genetik. Perubahan genetik bukan peristiwa yang menuju kelangsungan hidup suatu organisme melainkan adanya adaptasi terhadap lingkungannya dan adanya interaksi antara organisme dan lingkungannya. Dalam responnya organisme mengubah kondisi lingkungan, membangun struktur biologi tertentu yang ia perlukan untuk tetap bisa mempertahankan hidupnya.

\section{b. Pembelajaran Bervisi SETS (Science, Environment, Technology, Society)}

Wawasan SETS (Science, Environment, Technology, Society) yang diaplikasikan ke dalam proses pembelajaran Fisika diharapkan dapat membawa sistem pembelajaran untuk menghasilkan lulusan yang dapat menerapkan pengetahuan yang diperolehnya guna meningkatkan kualitas hidup manusia tanpa harus membahayakan lingkungannya. Pembelajaran berwawasan SETS menurut Binadja pendekatan yang paling dianjurkan adalah pendekatan SETS itu sendiri. 
Karakteristik pendekatan SETS dalam proses pembelajaran Fisika dapat disebutkan beberapa diantaranya sebagai berikut : (1) bertujuan memberi pembelajaran Fisika secara kontekstual, (2) siswa dibawa ke situasi untuk memanfaatkan konsep Fisika ke bentuk teknologi untuk kepentingan masyarakat, (3) siswa diminta berpikir tentang berbagai kemungkinan akibat yang terjadi dalam proses pentransferan konsep Fisika ke bentuk teknologi, (4) siswa diminta untuk menjelaskan keterhubungkaitan antara unsur konsep Fisika yang diperbincangkan dengan unsur-unsur lain dalam SETS yang mempengaruhi berbagai keterkaitan antar unsur tersebut., (5) siswa dibawa untuk mempertimbangkan manfaat atau kerugian dari penggunaan konsep Fisika bila diubah dalam bentuk teknologi yang relevan, (6) siswa diajak membahas tentang SETS dari berbagai arah dan dari berbagai titik awal tergantung pengetahuan dasar yang dimiliki siswa bersangkutan.

Pendekatan SETS dalam pembelajaran Fisika dapat diterapkan pada semua konsep-konsep Fisika kecuali ada keterbatasan pada konsep Fisika teori yang memerlukan kecepatan mendekati kecepatan cahaya untuk mempraktekkannya pada teknologi, misalnya pada konsep relativitas.

Konstruktivisme merupakan cara belajar yang menekankan peranan siswa dalam membentuk pengetahuannya sedangkan guru lebih berperan sebagai fasilitator yang membantu keaktifan siswa tersebut dalam membentuk pengetahuannya. Pengetahuan tidak dapat begitu saja dipindahkan dari otak seseorang (guru) ke kepala orang lain (siswa). Siswa sendirilah yang harus mengartikan apa yang telah diajarkan dengan menyesuaikan terhadap pengalaman-pengalaman mereka. Tanpa pengalaman, seseorang tidak dapat membentuk pengetahuan. Pengalaman disini tidak harus pengalaman fisik, tetapi bisa diartikan juga pengalaman kognitif dan mental. Banyaknya siswa yang salah menangkap apa yang diajarkan oleh gurunya (misconseptions), menunjukkan bahwa pengetahuan itu tidak dapat begitu saja dipindahkan, melainkan harus dikonstruksikan atau paling sedikit diinterpretasikan sendiri oleh siswa. Dalam proses kontruksi ini, diperlukan beberapa kemampuan:

1. Kemampuan mengingat dan mengungkapkan kembali pengalamannya

2. Kemampuan membandingkan, mengambil keputusan mengenai persamaan dan perbedaan

3. Kemampuan untuk lebih menyukai pengalaman yang satu daripada yang lain 
Tiap orang harus mengkonstruksi pengetahuan sendiri. Pengetahuan bukan sesuatu yang sudah jadi, tetapi proses yang berkembang terus menerus. Beberapa faktor seperti keterbatasan pengalaman kontruksi, struktur kognitif, dapat membatasi pembentukan pengetahuan orang.sebaliknya, situasi konflik atau anomali, akan megembangkan pengetahuan seseorang.

Selama dua puluh tahun terakhir ini, konstruktivisme telah banyak dipakai di Amerika, Eropa dan Australia. Prinsip-prinsipnya adalah:

1. Pengetahuan dibangun oleh siswa sendiri, baik secara personal maupun sosial

2. Pengetahuan tidak dapat dipindahkan dari guru ke murid, kecuali hanya dengan keaktifan murid sendiri untuk bernalar

3. Siswa aktif mengkonstruksi terus-menerus, sehingga selalu terjadi perubahan konsep menuju konsep yang lebih rinci, lengkap sesuai dengan konsep ilmiah.

4. Guru sekedar membantu menyediakan sarana dan situasi agar proses konstruksi siswa berjalan mulus.

Prinsip konstruktivisme sangat berbeda dan bahkan bertentangan dengan teori belajar behaviorisme (pelajar dipandang sebagai pasif, butuh motivasi luar, dan dipengaruhi reinforcement/penguatan) dan maturasionisme (pengetahuan tergantung pada tingkat biologis seseorang, umur menjadi norma yang penting bagi perkembangan pengetahuan seseorang)

Dalam bukunya, cooperative learning in the science classroom, Linda Lundgren menyebutkan bahwa unsur-unsur dasar dalam pembelajaran kooperatif sebagai berikut:

1. Para siswa harus memiliki persepsi bahwa mereka 'tenggelam atau berenang bersama'.

2. Para siswa memiliki tanggung jawab terhadap tiap siswa lain dalam kelompoknya, disamping tanggung jawab terhadap diri sendiri, dalam mempelajari materi yang dihadapi.

3. Para siswa harus berpandangan bahwa mereka semuanya memiliki tujuan yang sama.

4. Para siswa harus membagi tugas dan berbagai tanggung jawab sama besarnya diantara para anggota kelompok. 
5. Para siswa akan diberikan satu evaluasi atau penghargaan yang akan ikut berpengaruh terhadap evaluasi seluruh anggota kelompok.

6. Para siswa berbagi kepemimpinan sementara mereka memperoleh keterampilan bekerja sama selama belajar.

7. Para siswa akan diminta mempertanggungjawabkan secara individual materi yang ditangani dalam kelompok kooperatif.

\section{c. Pembelajaran Sains}

Pembelajaran ilmu pengetahuan alam atau sains dapat diuraikan sebagai berikut.

Belajar sains membantu siswa untuk memahami diri, lingkungan, dan alam, serta mendemonstrasikan pemahamannya ketika menyelesaikan masalah. Belajar sains tidak sekedar mempelajari informasi sains berkaitan dengan fakta, konsep, prinsip, hukum dalam wujud 'pengetahuan deklaratif' (declarative knowledge), akan tetapi belajar sains juga belajar tentang cara memperoleh informasi, cara dan teknologi (terapan sains), bekerja dalam wujud 'pengetahuan prosedural' (procedural knowledge), termasuk kebiasaan bekerja ilmiah dengan menerapkan metode dan sikap ilmiah.

Belajar sains memfokuskan kegiatan pada penemuan informasi melalui pengalaman sendiri yang rentang kegiatannya meliputi; mengamati, mengukur, mengajukan pertanyaan, mengelompokkan, merencanakan percobaan, mengendalikan variabel, mengumpulkan dan menata data yang dikehendaki, memecahkan masalah, dan memperjelas pemahaman.

Belajar sains memberi kesempatan siswa mengembangkan keterampilan dan pemahaman secara kontekstual dan bermakna. Belajar sains membiasakan sejumlah sikap ilmiah seperti sikap ingin tahu, jujur, bersungguh-sungguh, mau bekerja sama, terbuka dan luwes, tekun dan peduli lingkungan.

Belajar sains adalah mengembangkan sejumlah kompetensi adaptif yang sesuai dengan perubahan kondisi saat ini menuju kondisi masa depan, meliputi kemampuan merencanakan dan melaksanakan percobaan, kemampuan memilah, memilih, dan menata informasi, kemampuan menyimpulkan, dan kemampuan mengkomunikasikan serta menyempurnakan temuan. 
Belajar sains lebih bermakna dengan pengaitan sains dengan teknologi, lingkungan, dan masyarakat beserta segala aspeknya, dengan memperhatikan keseimbangan bahasan tentang unsur-unsur sains, lingkungan, teknologi, dan masyarakat secara berkaitan dan menyatu. Belajar sains memberi peluang terhadap pemikiran lebih mendalam tentang keterkaitan timbal balik antara sains, lingkungan, teknologi, dan masyarakat (salingtemas). Belajar sains mengkondisikan siswa agar mau dan mampu menerapkan prinsip sains untuk menghasilkan karya teknologi, disertai pemikiran munculnya dampak positif dan negatif yang mungkin timbul dari produk teknologi terhadap lingkungan dan masyarakat, serta isu-isu yang timbul di masyarakat sesudahnya untuk mengkaji kembali sains dan produk teknologi.

Belajar sains sebagai upaya membangun pemahaman dengan mempertimbangkan pengalaman dan pikiran yang sudah dimiliki siswa yang cenderung naif dan miskonsepsi.

Belajar sains adalah perubahan pembelajaran model 'indoktrinasi' menjadi pembelajaran model ‘pemberdayaan’ atau minimal model ‘pengkondisian’. Belajar sains adalah perubahan pembelajaran dengan fokus 'guru mengajar' menjadi pembelajaran dengan fokus 'siswa belajar'.

Belajar sains bukan hanya ditujukan untuk anak pandai melainkan untuk semua siswa dengan beragam kemampuan.

Belajar sains adalah membantu siswa dalam mengembangkan sejumlah keterampilan ilmiah untuk memahami perilaku/gejala alam, meliputi keterampilan mengamati dengan semua indera, menggunakan alat dan bahan, merencanakan eksperimen, mengajukan pertanyaan, merumuskan hipotesis, melakukan percobaan, menyimpulkan, dan mengkomunikasikan temuan dengan bahasa yang sesuai untuk keperluan itu.

Belajar sains adalah mengajak siswa memikirkan berbagai sumber sains serta mengambil manfaat darinya.

Belajar sains bukan ditentukan oleh didaktik metodik ‘apa yang akan dipelajari’ saja, melainkan pada bagaimana menyediakan dan memperkaya pengalaman belajar siswa, 
berdasarkan pada pemikiran 'mengapa' dan untuk apa siswa perlu mempelajari sesuatu tersebut.

Belajar sains adalah memberdayakan siswa agar mau dan mampu berbuat untuk memperkaya pengalaman belajarnya (learning to do), mampu memahami pengetahuannya berkaitan dengan dunia di sekitarnya (learning to know), dapat membangun pengetahuan dan kepercayaan diri sekaligus membangun jati diri (learning to be), dan memberi kesempatan berinteraksi dengan berbagai kelompok individu yang bervariasi yang akan membentuk kepribadiannya untuk memahami kemajemukan dan melahirkan sifat-sifat positif dan toleran terhadap keanekaragaman dan perbedaan masing-masing individu (learning to live together).

Belajar sains adalah untuk memelihara keingintahuan anak, memotivasinya sehingga mendorong siswa untuk mengajukan keragaman pertanyaan seperti 'apa, mengapa, dan bagaimana' terhadap obyek dan peristiwa yang ada di alam, yang dapat ditingkatkan menjadi pertanyaan yang menanyakan hubungan 'bagaimana jika ....', sehingga sebagai hasil eksplorasi terhadap lingkungan, siswa diharapkan membentuk dirinya dengan sikap seorang ilmuwan cilik. Belajar sains memberi kesempatan siswa sebagai 'young scientist' (peneliti muda) yang mempunyai rasa keingintahuan (curiousity) yang tinggi, yang mampu mengajukan pertanyaan, menduga jawabannya, merancang penyelidikan, melakukan percobaan, mengelola dan mengolah data, mengevaluasi hasil, dan mengkomunikasikan temuannya kepada beragam orang dengan berbagai cara yang dapat memberi pemahaman yang baik.

Belajar sains melahirkan interaksi antara gagasan yang diyakini siswa sebelumnya dengan suatu bukti baru untuk mencapai pemahaman baru yang lebih saintifik, melalui proses eksplorasi untuk menguji serta menguji gagasan-gagasan baru, dengan melibatkan beragam sikap ilmiah seperti, menghargai gagasan orang lain, terbuka terhadap gagasan baru, berpikir kritis, jujur, kreatif, dan berpikir lateral (berpikir yang tak lazim, di luar kebiasaan, atau yang mungkin dianggap aneh).

Belajar sains adalah memulai pelajaran dari 'apa yang diketahui siswa', tidak dapat mengindoktrinasi gagasan saintifik supaya siswa mau mengganti dan memodifikasi gagasannya yang non-saintifik menjadigagasan/pengetahuan saintifik, karena arsitek peubah gagasan siswa adalah siswa itu sendiri. 
Belajar sains adalah menyediakan 'kondisi' supaya proses belajar untuk memperoleh konsep yang benar dapat berlangsung dengan baik, dengan kondisi belajar antara lain : diskusi yang menyediakan kesempatan agar semua siswa mau mengungkapkan gagasan, pengujian dan penelitian sederhana, demonstrasi, dan peragaan prosedur ilmiah, dan kegiatan praktis lain yang memberi peluang siswa untuk mempertanyakan, memodifikasi, dan mempertajam gagasannya.

Belajar sains adalah melatih siswa sejak dini untuk mengatasi masalah-masalah yang dihadapinya agar memiliki kemampuan-kemampuan yang bermanfaat bagi kehidupan kelak khususnya setelah dewasa, meliputi : mengidentifikasi dan mengenali masalah; merencanakan penyelidikan; memilih teknik, alat dan bahan; mengorganisasi dan melaksanakan penyelidikan secara sistematik; menginterpretasikan data pengamatan; mengevaluasi prosedur kerja dan menyarankan perbaikan.

Belajar sains adalah berubahnya pola pembelajaran yang diawali dengan Penjelasan Uraian Materi (U) - dilanjutkan Contoh Soal ( C ) — dan Latihan Aneka Masalah (L) menjadi diawali dengan Latihan dengan Masalah (L) - dilanjutkan Penjelasan Materi (U) - dan Contoh Soal ( C ).

Belajar sains adalah menyediakan kegiatan pembelajaran yang bermuatan nilai, dengan menumbuhkan sikap ilmiah antara lain sikap ingin tahu, jujur, tekun, terbuka terhadap gagasan baru, tidak percaya tahayul, sulit menerima pendapat yang tanpa disertai bukti, kebiasaan merenung secara kritis, peka terhadap makhluk hidup dan lingkungan.

Kalau kita cermati sekolah menengah yang ada di sekitar, kita akan menjumpai kondisi para siswa yang tidak peduli terhadap lingkungan. Hal itu terindikasi dengan kenyataan-kenyataan yang ada, antara lain adalah :

1. Para siswa tidak peduli terhadap pohon-pohon yang ditanam, baik itu pohon peneduh maupun pohon-pohon untuk taman-taman di depan kelas, bahkan menunjukkan perilaku merusak dan sering mematikan pohon tanpa ada rasa tanggung jawab. Siswa tidak punya kegemaran menanam atau menyemaikan pohon atau bunga di taman depan kelasnya atau di lingkungan terdekatnya apalagi di tempat-tempat yang jauh dari kelasnya di lingkungan sekolah. Gejala ini pasti terbawa dan menjadi kebiasaan di lingkungan keluarga dan masyarakatnya, 
2. Para siswa tidak peduli lingkungan kelas dan sekolah yang kotor dengan tata kehidupan yang jorok-perilaku membuang sampah sembarangan-kertas, plastik,bungkus makanan, permen, tidak dibuang pada tempatnya, termasuk kejorokan yang dijumpai di WC putri, banyak bekas pembalut dibuang sembarangan. Dinding tembok di dalam maupun di luar kelas sering menjadi sasaran kaki sehingga selalu di jumpai jejak-jejak sepatu di tembok-tembok yang menimbulkan pemandangan kotor.

3. Para siswa bersikap apatis terhadap kerusakan lingkungan di dekat tempat tinggal mereka, misalnya lereng-lereng bukit yang gundul dan mudah longsor di musim penghujan dan biasanya merusak jalan. Merekapun apatis terhadap pemberitaantentang kerusakan lingkungan di wilayah lain, di tingkat lokal, regional, maupun nasional dan internasional. Mereka kurang memahami dan tidak mempunyai keprihatinan yang mendalam terhadap penderitaan yang menimpa bumi seperti efek rumah kaca, pemanasan global, kerusakan lapisan ozon,hujan asam dan sebagainya yang sudah menjadi masalah global.

Salah satu contoh pembelajaran yang dipandang atraktif, aktif dan kreatif adalah: Memberikan indoktrinasi kepada para siswa terutama pada jiwanya, bahwa penopang utama kehidupan manusia di bumi adalah pohon. Kekayaan dan kecukupan yang diterima manusia secara langsung maupun tidak langsung disuplai oleh pepohonan di bumi apapun jenis pohon itu. Oleh karena itu untuk mempercepat pemahaman indoktrinasi tersebut maka kegiatan pembelajaran outdoor selalu di bawah pohon secara berpindah berganti pohon pada hari yang berbeda. Setiap bagian pohon dibuat relevan dengan topik pembelajaran Fisika. Isaac Newton pun tidak akan menemukan hukum Gravitasi yang menggemparkan itu kalau Ia tidak sedang duduk-duduk di bawah pohon.

Pohon ditumbuhkan bumi; permasalahan lingkungan, kerusakan dan penderitaan bumi (menipisnya ozon, efek rumah kaca, dan lain-lain) dapat disembuhkan dengan menanam banyak pohon besar. Pernyataan-pernyataan tersebut diusahakan dapat menjadi pengertian yang mendalam di benak tiap-tiap siswa. Kerjasama dengan pengajar ekstra kurikuler untuk melatih kemampuan psikomotorik terhadap kecintaan kepada lingkungan di luar pembelajaran intra kurikuler Fisika selalu diadakan. Konsultasi dan konfirmasi selalu terjalin agar terjadi sinkronisasi pembelajaran ilmu alam yang menumbuhkan kepedulian terhadap lingkungan dengan menekankan aspek kognitif, afektif, dan psikomotorik secara terpadu. Hasil pembelajaran yang diharapkan pada siswa : 
1. Pemikiran siswa tidak kering berisi sains dan teknologi saja, tetapi kaya dan peka akan lingkungan, masyarakat, sains, teknologi beserta kesalingterkaitannya. Hal ini berarti pembelajaran Fisika yang dilakukan dengan pendekatan SETS sekaligus mendapat hasil penguasaan kompetensi materi Fisika dan teknologinya, kecintaan terhadap lingkungan dan kontekstualitas antara sains dengan lingkungan dan masyarakat sekitar dikuasai oleh para siswa. Sehingga pembelajaran Fisika tidak lagi menjadi pembelajaran yang serba menakutkan dan hanya di angan-angan melainkan menjadi pembelajaran yang konkrit mempelajari alam.

2. Kondisi tiap jengkal tanah di lingkungan sekolah menjadi hijau dan rimbun oleh pohon-pohon besar, taman-taman bunga, maupun sekedar rumput yang kesemuanya terawat rapi. Kecintaan para siswa terhadap tanaman tumbuh menebal dalam ukuran mayoritas jumlah siswa secara individual maupun per kelas secara kelompok.

3. Kepekaan terhadap masalah kerusakan lingkungan: tanah, air, maupun udara menjadi topik pembicaraan yang biasa diperbincangkan di kalangan para siswa. Diskusi tentang hal itu secara intens dilakukan pada pembelajaran Fisika dengan pendekatan SETS.

\section{KESIMPULAN}

Berbagai inovasi pembelajaran dapat dikembangkan untuk meningkatkan kepedulian siswa terhadap lingkungan secara umum adalah mengembangkan proses pembelajaran konstruktivis dengan pendekatan SETS dengan menggunakan model pembelajaran Discovery-Inquiry, memakai berbagai metode yang variatif sendiri atau gabungan: seperti lab work, diskusi kelompok, problem solving, studi kepustakaan. Proses pembelajaran dilakukan secara indoor atau outdoor. Kegiatan pembelajaran para siswa selalu dilakukan berkelompok, hal itu untuk lebih mengoptimalkan pembelajaran kooperatif sesuai dengan prinsip-prinsip dasar cooperative learning. Dengan demikian pembelajaran Fisika yang dilakukan mengesampingkan pembelajaran konvensional yang berorientasi pada materi sains dengan penyajian ceramah satu arah dari guru ke siswa. Pendekatan SETS dengan lingkungan sebagai fokusnya secara kontinu menjadi proses pembelajaran yang menumbuhkan kecintaan terhadap lingkungan sampai mendarah daging. 


\section{DAFTAR PUSTAKA}

Aidibarasa. (2013). Pengertian Bahan Ajar menurut buku dan para ahli.[Online].Tersedia: http://www.wordpress.pdf. (13 Januari 2013).

Brog and Gall. (2006). Educational Research, Longman, New York.

Depdiknas. (2009). Materi Diklat/Bimtek KTSP. Departemen Pendidikan Nasional. Jakarta

Dinata, Sukma .(2005). Metode Penelitian Pendidikan, PT Remaja, Bandung.

Mamat SB, Abdul Munir, dkk. (2005). Pedoman Pelaksanaan Pembelajaran Tematik. Departemen Agama RI. Jakarta.

Marno. (2011). Modul Pengembangan Bahan Ajar PAI pada Sekolah. Diktorat Pendidikan Agama Islam. Jakarta.

McMillan, J dan Schumacher, S. (2001). Research in Education: A Conceptual Introduction.New York: Addison Wesley Longman.

Mulyasa.(2008). Implementasi Kurikulum Tingkat Satuan Pendidikan, Kemandirian Guru dan Kepala Sekolah. Jakarta: Bumi Aksara.

Muslich, Masnur. (2007). KTSP Pembelajaran Berbasis Kompetensi dan Kontekstual . Bumi Aksara. Jakarta.

Prastowo, Andi. (2007). Pengembangan Bahan Ajar Tematik. Diva Press. Yogyakarta.

Prihantoro, Laksmi, dkk. (1996). Buku Materi IPA Terpadu. Karunika. Jakarta.

Rayandra Asyhar. (2012) Kreatif Mengembangkan Media Pembelajaran. Referensi. Jakarta.

Sugiono. (2010). Metode Penelitian Pendekatan Kuantitatif Kualitatif dan R\&D. Alfabeta. Bandung. 